Љиљана Ђурић

Универзитет у Београду

Филолошки факултет
UDC 371.3:81'243

DOI https://doi.org/10.18485/fid.2018.8.ch3

\title{
СТРАНИ ЈЕЗИЦИ У ЈЕЗИЧКОЈ ОБРАЗОВНОЈ ПОЛИТИЦИ СРБИЈЕ: ДИНАМИКА ПРОМЕНА У ПЕРИОДУ ОД 2000. ДО 2016. ГОДИНЕ
}

\begin{abstract}
Сажетак
Из перспективе анализе јавних политика, у раду се приказују динамика и карактер промена у језичкој образовној политици Србије - подобласт страних језика. У првом делу, као врста евалуације ex post имплементације утврђених решења, разматра се кохерентност најзначајнијих одлука донесених у периоду од 2000. до 2016. године као и њихове последице. У другом делу, својеврсној анализи in vivo конципирања нових решења у вези са пољуљаним статусом другог страног језика у основној школи, посматра се виђење појединих актера како суштине проблема тако и могућих решења. На основу резултата истраживања, предлажу се правци даљег развоја у тој области.
\end{abstract}

Кључне речи: језичка образовна политика Србије, јавна политика, страни језици, 2000 - 2016, актери.

\section{Уводне напомене}

Језичка образовна политика Србије остварује се у оквиру неколико наставних подобласти: српског као матерњег и као нематерњег језика, језика националних мањина које живе на територији Србије као матерњих језика и као језика друштвене средине, „страних језика“, под чим се подразумева учење такозваних светских језика или језика међународне комуникације - енглеског, немачког, француског и руског, којима су почетком XXI века додати италијански и шпански ${ }^{1}$.

1 Као факултативни страни језици могу се учити кинески, новогрчки итд. 
Предмет овог рада јесте подобласт страних језика, тачније, њена динамика ${ }^{2}$ у последњих петнаестак година, и то у првом реду у оквиру основног / обавезног образовања. (Опредељење за овај ниво образовања захтева образложење: основно / обавезно образовање намеће се с једне стане због тога што је темељ система, једини неселективни ниво образовања намењен целокупној популацији, и као такав, најзначајнији индикатор стварне праведности образовања ${ }^{3}$, што је значајно за анализу образовних политика; с друге стране, у протеклих 15 година на том нивоу образовања било је доста промена, што се не може рећи за опште средње образовање, где је мењан наставни програм, али не и наставни план. Треба напоменути поред тога да у општем средњем образовању мало шта постоји што на известан начин није уведено у основно образовање. ${ }^{4}$ )

У намери да прикажемо хронологију доношења и садржај најважнијих одлука које се у поменутом периоду односе на наставу страних језика, као и последице тих одлука у смислу промене језичке образовне политике, осврнућемо се кратко на деведесете година XX века како бисмо указали на континуитете и дисконтинуитете језичке образовне политике почев од 2000. године. Посебну пажњу посветићемо актуелном проблему статуса наставног предмета Други страни језик у основној школи, чију ћемо анализу у знатној мери засновати на проучавању корпуса текстова насталих у оквиру делатности различитих институционалних актера, али и појединаца: представника државних институција; истраживача, експерата и представника професионалних удружења; представника медија. Из истраживања произилазе закључци који су основа за конкретне предлоге којима закључујемо овај рад.

2 У складу са дефиницијом Клајн и Шипка 2007: Динамика: [...] 2. „редослед промена, начин развоја, распоред по коме се одвија неки процес“.

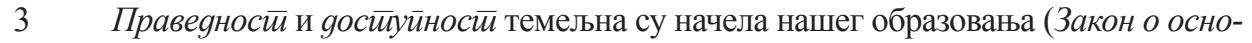
вама системе образовања и васиийања, Службени гласник РС, 72/2009, 52/2011, 55/2013, у делу Општи принципи, члан 3, наводи: 1) једнако право и доступност образовања и васпитања $[. .] ; 2$.$) квалитетно и уравнотежено [...] итд.).$ 
СТРАНИ ЈЕЗИЦИ У ЈЕЗИЧКОЈ ОБРАЗОВНОЈ ПОЛИТИЦИ СРБИЈЕ:

ДИНАМИКА ПРОМЕНА У ПЕРИОДУ ОД 2000. ДО 2016. ГОДИНЕ

\section{Теоријски оквир и методолошке напомене}

Језичку образовну политику - која је део језичке политике сваке земље и истовремено један од њених најважнијих инструмената - посматрамо као јавну политику; то значи да је теоријски оквир нашег истраживања анализа јавних политика ${ }^{5}-$ иначе најмлађа подобласт политичких наука -, схваћена пре свега као наука о држави у акцији (Милер 2006: 3), али и као анализа шире схваћене јавне акције која тражи одговоре на питања као што су:

- Ко дела?

- На који начин?

- Које и какаве одлуке доноси?

- На основу којих политичких, идеолошких, вредносних оријентација?

- Са каквим последицама?

Ослањајући се на истраживања која за предмет имају јавну управу, на теорију организација и на проучавање јавног менаџмента, анализа јавних политика користи аналитички апарат који садржи

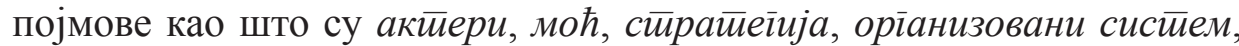
ексиеритиза итд. (Милер 2006: 15, 18, 19), помоћу којих тежи да проникне у црну куйију државе и разуме не само „од којих детерминанти она зависи, већ и на који начин функционише“" (Милер 2000: 192). Разумевање утицаја / одсуства утицаја релевантних актера из цивилног сектора на оно што се збива у тој црној куйији такође је битна тежња истраживача у области анализе јавних политика.

Први део овог рада разматра деловање државних институција надлежних за образовање ${ }^{6}$ кроз инструменте којима се језичка образовна политика имплементира у систем образовања, док се други део, анализа случаја Други страни језик у основној школи, бави различитим релевантним актерима и њиховим виђењем проблема који заокупља пажњу стручне и лаичке јавности почев од фебруара 2016. С обзиром на потребе и обим рада, истраживање је спроведено тако што се у првом делу

5 Напомињемо да је у питању теоријски оквир који се у значајној мери ослања и на постулате макросоциолингвистике, као и критичке социолингвистике.

6 Први део овог рада ослања се у знатној мери на шире истраживање спроведено у оквиру докторске дисертације објављене 2016. (Ђурић 2016). 
посматрају већ донесене одлуке (у првом реду анализа ex post њихове кохерентности), преточене у законска и подзаконска акта, док се у другом посматра део процеса који претходи доношењу одлуке - у нашем случају, одлуке у вези са пољуљаним статусом наставног предмета Други страни језик која, у тренутку када саопштавамо ово истраживање ${ }^{7}$, још није донесена или још није нормативно уобличена.

Опредељење да се у оквиру првог дела рада ослонимо такорећи искључиво на корпус нормативног карактера, то јест регулативу која делује по моделу одозго-на-доле, не значи да политичке процесе одоздо-на-горе не сматрамо значајним; наше становиште јесте, међутим, да упркос важности тих процеса током осмишљавања решења, јавну политику in fine чини ипак оно што одлучи (или не одлучи) држава.

Неки од суштинских постулата аналитичког приступа помоћу „три и“ (идеје, интереси, институције) - који „омогућује превазилажење извесних ограничења својствених класичним правцима анализе јавних политика““ (Сирел 2014: 650) - узети су у обзир у другом делу рада у којем тежимо да покажемо разлике у сагледавању одређеног конкретног проблема из области језичке образовне политике и виђење његових могућих решења.

\section{Анализа промена по периодима}

Промене језичке образовне политике Србије могу се пратити кроз области система образовања које су од посебног значаја за наставни предмет Страни језик: 1. Статус страних језика, наставни план и програм; 2. Образовни стандарди; 3. Уџбеници; 4. Наставници 8 ; 5. Иновативни пројекти.

Како обим рада не дозвољава, међутим, да се прикаже анализа свих наведених области, највише пажње биће посвећено статусу страних језика и наставном плану који им је додељен, као и последицама промена којих је било у периоду који проучавамо.

7 Почетак школске 2016/2017. године.

8 У контексту који одређује ово истраживање, најважније питање у вези са наставним кадром односи се на обезбеђивање квалификованих наставника страних (енглеског) језика. 


\section{а) Деведесете године XX века ${ }^{9}$}

У периоду од 1991. до 2000. године ${ }^{10}$ у основној школи задржава се раније успостављен систем: страни језик се као изборни предмет учи од III до VIII разреда ${ }^{11}$, а страни језик као обавезни предмет од V до VIII разреда ${ }^{12}$. Овај модел, који се почетком осамдесетих година XX века прво развио у београдским основним школама (те се неретко назива „београдски модел“"), ширио се постепено у унутрашњости: „Из достављених података који се односе на опредељеност ученика за наставу страног језика као изборног предмета види се да се од 28388 ученика трећег разреда, 20 173 ученика, односно 71,06\%, определило за учење страног језика као изборног предмета“ (Јановски 2000: 22).

Укупан фонд часова за оба језика приближно је био исти на крају основне школе (око 400 школских часова), што је омогућавало ученицима да бирају језик који ће наставити да уче уколико настављају школовање у средњој стручној школи.

Ученици који су се опредељивали за средње школе у којима се уче два страна језика (гимназије, средње економске и средње туристичко-угоститељске), настављали су да уче оба језика.

Намера законодавца била је, дакле, да се у основној школи избегне наметање хијерархије језика (у основи тог решења препознаје се утицај Друштва за стране језике и књижевности Србије које је деценијама заступало мишљење да је потребно уравнотежено учење сва четири школска језика, с обзиром на политику несврстаности и генерално на потребу да као друштво „гледамо на све четири стране света“", како се тада говорило), док је у средњој школи законодавац препуштао ученицима успостављање те хијерархије, то јест одлуку који ће језик за њих бити први, а који други. Такође, настављањем учења језика који су започети у основној школи тежило се постизању солидног нивоа знања из оба језика на крају предуниверзитетског образовања.

Па ипак, у томе периоду раскорак између нормативне уређености и стварности може се уочити већ на следећем примеру: разрађују се

9 Опширније у Ђурић 2016, стр. 276-288.

10 Овај систем важио је de facto до 2003. године за ученике који су уписали основну школу по закону из 1991.

11 По два школска часа недељно у свих шест разреда.

12 Четири школска часа недељно у V, три у VI, по два у VII и VIII разреду. 
мање или више озакоњене могућности мењања језика после основног образовања (напуштање „нежељеног“ / „некорисног“ и учење ,жељеног“ / „корисног“ језика по почетном наставном програму), чиме се, посебно у гимназијама, јавља непродуктивна конкуренција међу језицима, а истовремено се на крају средње школе постиже нижи ниво знања него у случају континуираног учења истог / истих језика. Још један драстичан, иако мало познат, пример одступања од званичне језичке образовне политике са далекосежним последицама јесте одлука Актива директора београдских гимназија да, наводно из практичних разлога, наметну енглески језик као једини први страни језик (Ђурић 2016: 278).

Реч је, видимо, о прикривеном (или нехотичном?) заокрету у језичкој образовној политици, чије последице појачавају извесне тенденције видљиве већ осамдесетих година XX века:

- Све веће ширење енглеског језика, de facto на штету других језика (што није било неизбежно ${ }^{13}$, већ је последица недоследности у спровођењу договорене политике), и јачање његовог културног, политичког и друштвеног “легитимитета"; учвршћује се лаичко некритичко уверење да је у питању lingua franca која се “природно” наметнула у процесима глобализације;

- Све веће социјално раслојавање и неуравнотежена локална расподељеност између села и града у погледу језика који се уче и, следствено томе, незадовољство ученика и родитеља који се сматрају оштећени уколико не уче жељени језик;

- Улазак великог броја нестручних наставника ${ }^{14}$, у првом реду енглеског језика, у систем образовања.

\section{б) 2001-2004: реформа основног и средњег образовања}

Уочи свеобухватне реформе започете 2001. године учење страног језика од I разреда основне школе доспело је на йолийичку аїен-

13 Уз мало труда просветних власти, посебно на локалном нивоу, могло се омогућити свим ученицима учење два језика, од којих би један свакако био енглески.

14 Према подацима за школску 1999/2000. годину „највише [jе] неодговарајућег наставног кадра, више од 30\%, у школама Браничевског, Јужнобанатског, Средњобанатског, Сремског, Севернобанатског и Подунавског округа. Најмање је у Топличком округу где је само 6,45\% наставника без прописане стручне спреме““ (Јановски 2000: 10, 11). 
$g y^{l 5}$. Концепција реформисане основне школе предвиђала је следећа решења: први страни језик стављен је на листу основних наставних предмета (оних који се уче од почетка до краја школовања); други страни језик предвиђен је као обавезан наставни предмет од почетка другог циклуса; у трећем циклусу ${ }^{16}$, за заинтересоване ученике, предвиђена је могућност факултативног учења још једног језика (укључујући и језика друштвене средине). Понуда страних језика проширена је додавањем италијанског и шпанског језика.

\section{в) 2004-2007. и даље...}

Промена политичке власти 2004. године доводи до обустављања реформе и до укидање наставе страног језика у I и II разреду основне школе. Па ипак, већ 2005. године, нови министар просвете у Влади истог премијера враћа страни језик као обавезан наставни предмет од I разреда основне школе. 2007. године уводи се други страни језик као обавезно изборни йреgмей са фондом од два часа недељно, од $\mathrm{V}$ до VIII разреда. Овај не баш јасан статус дефинисан је на следећи начин: „Ученик бира страни језик са листе страних језика коју нуди школа у складу са својим кадровским могућностима и изучава га до краја другог циклуса““ (Правилник о наставном плану за други циклус основног образовања и васпитања). Током тих година и даље, за одговарајуће разреде доносе се наставни програми за први и за други страни језик.

У том периоду, у протеклој деценији дакле, иако још недостају образовни стандарди за страни језик у основној школи (у изради су тек од новембра 2015.), због чега тај наставни предмет није заступљен на завршном испиту у основној школи, захваљујући чињеници да је најинтензивнија активност државних институција тада била доношење нових наставних планова и програма за основну школу, може се рећи да jе концепција наставе страних језика у приличној је мери заокружена:

15 Полийичка аїенgа садржи сва питања која се сматрају битном темом јавних расправа, па чак и предметом интервенције легитимне политичке власти (Падиоло in Милер 2006: 29-30).

16 Било је предвиђено да основно / обавезно образовање траје девет година, са три циклуса од по три разреда. 
- Предвиђено је обавезно учење два страна језика, од којих је један, најчешће први, енглески, а други неки од следећих језика: италијански, немачки, руски, француски, или шпански;

- Избор језика који ће се у датој школи нудити у надлежности је самих школа које више нису у обавези да за евентуалне промене траже одобрење Министарства;

- Први и други језик уче се, међутим, са веома различитим фондом часова: први страни језик (у огромној већини школа енглески, иако то није обавезно) са око 600 школских часова, и други страни језик са око 300 школских часова.

Такво стање, поред позитивних учинака - у првом реду обезбеђивање минималних услова за развој вишејезичности, што је и опредељење исказано у Закону -, има и негативне последице:

- Велика неравнотежа у знању првог и другог језика на крају основне школе, чиме су условљена даља опредељења ученика;

- Наметнутом хијерархијом језика Србија се приближила језичкој образовној политици познатој као модел English only (то јест, целокупна школска популација учи једино или у највећој мери језик који се проглашава „најкориснијим“ (Беако 2001: 3), а чија се „корисност“ некритички сагледава као универзална и неупитна датост, просторно и временски непроменљива; у основи овог модела је идеологија економије језика $\left.{ }^{17}\right)$.

\section{г) 2013. година}

Доношењем новог Закона о основном образовану и васиичйању смањен је укупан максималан фонд часова који ученици могу имати у основној школи, чиме је отворен проблем статуса другог страног језика, једног од наставних предмета због којих се тај фонд пробија у VII и VIII разреду.

17 Језичке идеологије ,укључују поимања о квалитету, вредности, статусу, нормама, функцијама, власништву итд.“ језика (Бломерт іn МекГроарти 2009: 98). 
СТРАНИ ЈЕЗИЦИ У ЈЕЗИЧКОЈ ОБРАЗОВНОЈ ПОЛИТИЦИ СРБИЈЕ:

ДИНАМИКА ПРОМЕНА У ПЕРИОДУ ОД 2000. ДО 2016. ГОДИНЕ

\section{Анализа случаја други страни језик у основној школи}

Иако је нови закон донет још 2013. године, проблем неусаглашености наставног плана и максималног фонда часова уочен је тек јануapa 2016. када је Заштитник грађана упутио захтев министру просвете да се наставни план усклади са Законом; министар је захтев проследио Заводу за унапређивање образовања и васпитања који је формирао комисију (јавности непознатог састава, али свакако без представника Српске академије наука и уметности, Заједнице филолошких и филозофских факултета и Друштва за стране језике и књижевности Србије) ради изналажења одговарајућег решења; о могућности укидања обавезности учења другог страног језика у основној школи, незванично и у пола гласа, говори се већ почетком фебруара 2016.

Неки од кључних момената каријере ирроблема ${ }^{18}$ статуса другог страног језика могли би се резимирати, стога, на следећи начин:

- Проблем настаје 2007. године када се другом страном језику додељује проблематичан статус и преполовљен фонд часова у односу на први страни језик; о тој суштинској промени језичке образовне политике државне инстанце нису тражиле мишљење академске заједнице ${ }^{19}$;

- Последица тог стања јесте постепени, прећутан, прелазак на модел English only, али и у наставном програму (циљеви, исходи), и у пракси, изостаје императив достизања високог нивоа постигнућа у знању енглеског језика, како је то уоби-

18 Каријера ирроблема јесте појам који у анализи јавних политика подразумева неколико фаза: појављивање проблема које бива потенцирано неочекиваним догађајима; следе дебате које доводе до спецификације проблема и јављања мање више супротстављених пројеката за његово решавање; ширење проблема у јавности кроз објављивање дебата; улазак проблема у формални систем доношења политичких одлука (Падиоло іп Милер 2006: 30-31).

19 То мишљење Друштво за стране језике и књижевности Србије дало је још 2006. године када је у допису упућеном Министарству захтевало да се другом страном језику додели исти фонд часова који је раније имао Страни језик као обавезни предмет $(4,3,2,2)$. Министарство га није уважило, као ни предлог, који је подржао Савез учитеља Србије, да се други страни језик уведе од IV разреда. 
чајено у државама које су се определиле за поменути модел (на пример скандинавске земље);

- Доношењем новог Закона о основном образовању и васпитању 2013. прописује се нови максимални фонд часова, смањен за два часа, не водећи рачуна о наставним предметима већ заступљеним наставним планом.

Откада је питање статуса другог страног језика постао проблем о којем се јавно расправља, од фебруара 2016. дакле, неки од најзначајнијих актера језичке образовне политике изјаснили су се о њему у медијима. Како смо већ напоменули, иниеереси, иgеје и инсииийуције представљају значајне димензије у анализи јавних политика. Ако узмемо само категорију иgеје, то јест „интелектуалну димензију јавних политика“, морамо сагледати бар неке од следећих компоненти, на пример: дијагнозу проблема; исказане вредности и циљеве; норме јавне акције (пре свега место државе); инструменте; слике или моделе (Палије и Сирел 2005: 16). Будући да пратимо генезу решења која још нису утврђена, јавни дискурс актера анализирали смо кроз две компоненте:

A/ дијагноза проблема или виђење његове суштине,

Б/ могућа решења или алтернативе у оптицају.

Анализирани корпус наведен у Литератури на крају овог рада, обухвата две основне категорије актера: представнике државних институција, представнике научне и стручне заједнице (експерти).

\section{А/ Синтетички приказ виђења суштине проблема}

\section{Представници државних институција:}

- Пробијање максималног броја часова дефинисаног Законом о основном образовању и васпитању из 2013;

- Непостојање страног језика међу обавезно изборним наставним предметима у Закону о основама система образовања и васпитања.

Експерти и наставници страних језика, уколико би се укинула обавезност учења другог страног језика:

- Ц Цивилизацијско назадовање; 
- Раскорак између прокламоване политике вишејезичности и сталне тежње да се у стварности наметне модел English only;

- Одустајање од европске језичке образовне политике вишејезичности;

- Стварање још већег јаза између сиромашних и добростојећих ученика;

- Значајно слабије језичко образовање у односу на друге европске земље ${ }^{20}$ и немогућност наших ученика да се равноправно укључе на европско и светско тржиште рада;

- Прекаризација професије наставника страних језика.

\section{Б/ Синтетички приказ виђења решења: алтернативе у оптицају}

Предлози Завода за унапређивање образовања и васпитања:

- Други страни језик обавезан наставни предмет у V и VI разреду, изборни у VII и VIII; или

- Други страни језик изборни предмет од V до VIII разреда.

\section{Министар просвете, науке и технолошког развоја:}

- Предлог, који по речима министра др Срђана Вербића “неће бити формално-правне природе већ суштинске”, најављен је за почетак маја 2016, али, уколико је сачињен, није представљен јавности. Ни нови министар Младен Шарчевић, изабран 8. августа 2016, на почетку свог мандата није, колико смо могли да утврдимо, давао изјаве на ту тему ${ }^{21}$.

20 Упоредно истраживање радне групе коју је фебруара 2016. формирало Друштву за стране језике и књижевности Србије (поређење Србије са Француском, Италијом, Немачком и Русијом) показало је да обавезно образовање најкраће траје у Србији, да је укупан недељни број часова најмањи у Србији, да је фонд часова за први страни језик најмањи у Србији, а да је за други страни језик најмањи у Србији и Русији (Материјал је дат у прилогу овог Зборника).

21 Претраживање Интернета 16. септембра 2016. показало је да се министар Шарчевић до тог датума изјашњавао о оцењивању наставника, дуалном образовању, продужењу рока завршавања студија студентима уписаним по старом закону, враћању униформи у школе, мењању Закона о уџбеницима, увођењу кратких физичких вежби пре сваког часа и сл. 


\section{Национални просветни савет:}

- Председник овог тела, др Александар Липковски, заложио се за промену Закона, то јест за повећање укупног фонда часова.

\section{Експерти, наставници страних језика:}

- Други страни језик треба да постане обавезан наставни предмет са појачаним фондом часова;

- $\quad$ С тим у вези, тражи се промена Закона и повећање укупног фонда часова.

\section{Закључне напомене}

Спроведено истраживање, иако се односи искључиво на статус и наставни план наставног предмета Страни језик (први и други) у основној школи, омогућује нам да издвојимо неке битне карактеристике савремене језичке образовне политике у подобласти страних језика у Србији. Та подобласт, маргинализована у последњих дванаестак година $^{22}$, поред тога што је нејасно и непотпуно регулисана, у несагласју је са другим секторима јавне политике, пре свега са тежњом Србије да постане чланица Европске уније, као и Међународне Организације Франкофоније, чији је посматрач већ десет година. Ипак, може се рећи да такво стање представља одређени континуитет са стварном (не и са прокламованом, разуме се) језичком образовном политиком у области страних језика вођеном деведесетих година XX века.

22 Од враћања страног језика у І разред основне школе па до отварања случаја Други страни језик у основној школи, та подобласт језичке образовне политике није привлачила пажњу политичара и медија. Иако многи актери константно исказују одређени степен незадовољства како језичком образовном политиком у тој подобласти тако и компетенцијом ученика, државне институције нису ни покушале да утврде оправданост / неоправданост неких од тих критика. Истраживања се спроводе у оквиру научних установа и стручних удружења, али њихови резултати тешко проналазе пут до доносилаца одлука и до шире јавности. 
Оба приступа у истраживању, како анализа ex post имплементације утврђених решења тако и анализа in vivo конципирања нових решења, потврђују и овог пута претпоставку да јавне политике (њихова генеза, институционализација и, евентуално, евалуација ${ }^{23}$ ) нису кохерентни процеси, као и да актери, у нашем случају пре свега доносиоци одлука и њихови саветници, нису увек вођени до краја рационалним разлозима, већ су неретко ограничени постојећим институционалним решењима, а још више својим идеолошким заблудама, понекад и неспособношћу да изграде визију развоја области којом руководе и увиде последице одлука које доносе. Илустративан пример те оіраничене рационалносии $u^{24}$ јесте управо Закон из 2013. који је без стварне потребе отворио проблем неусклађености нових прописа са већ постојећим наставним планом, угрозивши при том саму суштину језичке образовне политике Србије и обавезе које је преузела када је постала земља чланица Савета Европе и кандидат за учлањење у Европску унију и у Међународну Организацију Франкофоније.

Посебно је значајна (зачуђујућа) чињеница да се у кључним тренуцима - приликом увођења другог страног језика 2007, или решавања проблема прекорачења максималног фонда часова 2016. надлежне институције нису обратиле експертима за ту подобласт, штавише, игнорисале су веома корисне и применљиве предлоге. Наше истраживање, иако то није био првобитни циљ, у проучаваном периоду утврђује постојање озбиљних проблема на релацији доносиоци одлука - експерти: „Да би се разумело појављивање дате јавне политике, треба почети са идентификовањем различитих актера и са разматрањем односа који их повезују““ (Милер 2006: 32). Ову појаву означили бисмо као пример дисконтинуитета у односу на деведесете године XX и реформске године с почетка XXI века, када су комисије увек формиране тако да укључују и експерте за стране језике.

23 Евалуација јавних политика није постала уобичајени део њиховог развоја у Србији.

24 Појам оіраничене рационалносиии увели су још шездесетих година XX века Марч и Сајмон (J. March, H.Simon, Les organisations, Paris, Dunod, 1964). По овим ауторима, доносиоци одлука нису ни сасвим рационални нити ирационални, већ је „рационалност њиховог делања парцијална, фрагментарна, ограничена“ (in Милер 2006: 37). 
Истакнимо, на крају, неуобичајено висок степен респонзивности $^{25}$ прворазредне научне институције као што је Српска академија наука и уметности, као и Заједнице филолошких и филозофских факултета; те институције, које у анализираном периоду нису реаговале на решења која смо оценили као промену језичке образовне политике, сада то чине показујући да су спремене за проактивно бављење овим питањима.

Стога рад завршавамо предлогом да се отварање проблема опстанка другог страног језика у основној школи као обавезног наставног предмета схвати као ирилика за йобољмање иоложаја ${ }^{26}$ језичког образовања уопште, те да се оснује радна група састављена од представника Српске академије наука и уметности, Заједнице филолошких и филозофских факултета и Друштва за стране језике и књижевности Србије ради израде документа који би утврдио главне правце развоја језичке образовне политике (укључујући и њене процедуралне аспекте), у складу са нашом традицијом, европском језичком образовном политиком ${ }^{27}$ и, надасве, потребама развоја и појединаца и земље чији је пресудан чинилац сарадња и повезаност са окружењем и светом.

25 Мислимо на питање статуса Другог страног језика у основној школи који је био и повод наших окупљања 14. марта - на Филолошком факултету Универзитета у Београду, и 26. маја 2016. године - у Српској академији наука и уметности.

$26 \mathrm{У}$ анализи јавних политика говори се о policy window или о fenêtre d'opportunité.

27 За политику неговања вишејезичности у складу са концепцијом Савета Европе описаном у следећој дефиницији: „У сржи оваквог проактивног става према језицима и очувању језичке разноликости је идеја да будућа покољења Европљана треба да се развијају у правцу познавања и употребе већег броја различитих језика, са различитим нивоима компетенције и са јасно препознатим друштвеним (укључујући и професионалне) контекстима њихове употребе“" (Филиповић 2007), залаже се већ деценијама и аутор овог чланка. 


\section{Референце:}

\section{I Корпус}

\section{А/ Законска и подзаконска акта}

Закон о основама система образовања и васпитања, Службени йласник PC, 72/2009, 52/2011, 55/2013;

Закон о основном образовању и васпитању, Службени йласник $P C$, 2013;

Правилник о наставном плану за други циклус основног образовања и васпитања и наставном програму за пети разред основног образовања и васпитања, Просветини иррейлеg, 2007.

\section{Б/ Текстови са изјашњавањем различитих актера}

Секеруш, Павле, дневни лист Данас, 11. март 2016;

Андрић, Весна, дневни лист Данас, 13. март 2016;

Гуцијан, Сандра, дневни лист Полийика, 13. март 2016;

Андрић, Весна, дневни лист Данас, 9. април 2016;

Андрић, Весна, дневни лист Данас, 19. април 2016;

Липковски, Александар, веб-портал Зелена учионица, 17. мај 2016. (извор: Танјуг).

Записници са састанака ДСЈКС;

Допис Удружења професора француског језика министру просвете, науке и технолошког развоја Републике Србије (17.II 2016. године); Записник са састанка представника Српске академије наука и уметноисти, Заједнице филолошких и филозофских факултета и Друштва за стране језике и књижевности Србије (14.III 2016. године);

Упоредна анализа положаја страних језика у системима образовања Србије, Француске, Италије, Немачке и Русије (радна група Друштва за стране језике и књижевности Србије).

\section{ІІ Цитирана дела}

Беако (2001): Beacco, J-C. Les idéologies linguistiques et le plurilinguisme. In: Le Français dans le Monde, n. 314. (пагинација је дата на 
основу електронске форме текста доступне на сајту www. observatoireplurilinguisme.eu; сајт консултован 2013.)

Ђурић (2016): Ђурић, Љ. Сйрани језищи у образовној йолитиици Србије. Београд: Филолошки факултет Универзитета у Београду;

Јановски (2000): Janovski, K. Nastava stranih jezika u osnovnim školama na početku reforme i novog milenijuma. Primenjena lingvistika broj 1. Нови Сад: југословенско друштво за примењену лингвистику и Филозофски факултет у Новом Саду, стр. 1-30.

Клајн, Шипка (2007): Клајн, И., Шипка, М. Велики речник сиираних речи и израза, Прометеј;

Комисија за развој школског програма (2003): Реформа образоваға у Рейублищи Србији: иколски йроїрам. Конщейщчиј, стирайеїија, имйлеменйација, МПСРС.

МекГроарти (2009): McGroarty, M., The Political Matrix of Linguistic Ideologies, in: B. Spolsky, F. Hult (eds.), The Handbook of Educational Linguistics. Blackwell Publishing.

Милер (2006): Muller, Р. Les politiques publiques. Paris: Presses universitaires de France. (6 ${ }^{\text {ème }}$ édition mise à jour, 1 ère édition 1990).

Милер (2000): Muller, P. L'analyse cognitive des politiques publiques : vers une sociologie politique de l'action publique. In: Revue française de science politique, 50 ${ }^{\mathrm{ème}}$ année, numéro 2, 2000. pp. 189-208.

Палије, Сирел (2005): Palier, B. et Surel, Y. Les « trois I » et l'analyse de l'État en action. In: P. Muller. Revue française de science politique, vol. 55, $\mathrm{n}^{\circ}$ 1. Paris: Presses de Sciences Po. pp. 7-32.

Сирел (2014): Surel, Y. « Trois I », In : Boussaguet et al., Dictionnaire des politiques publiques, Paris : Presses de Sciences Po. (4 ${ }^{\text {ème }}$ édition, $1^{\text {ère }}$ édition 2004), pp. 650-657.

Филиповић, Вучо, Ђурић (2007): Filipović, J., Vučo, J., Đurić, Lj., Critical Review of Language Education Policies in Compulsory Primary and Secondary Education in Serbia. In: Currrent issues in Language Planning. - VIII, 2, 222-242.

Филиповић(2009):Filipović, J.Moćreči. Ogledi izkritičkesociolingvistike. Beograd: Zadužbina Andrejević; 


\title{
Ljiljana Đurić
}

\section{FOREIGN LANGUAGES IN SERBIAN \\ LANGUAGE EDUCATION POLICIES: DYNAMICS OF CHANGES (2000-2016)}

\begin{abstract}
Summary
Herein, dynamics and nature of changes in foreign language education policy in Serbia (2000-2016) are presented. In the first part of the paper, a review of coherence and consequences of the most important decisions made from 2000 to 2016 is provided from the perspective of curricular changes in foreign language educational policy. Both positive effects and negative consequences of those changes are identified, the most important one being an imbalance in the learning outcomes in first and second foreign languages at the end of primary education, which results in creation of a specific hierarchy of foreign languages among students.

The second part of the paper presents an in vivo analysis of new solutions for the status of second foreign languages in the educational system, examines views of individual actors in this process, and investigates possible solutions through a corpus of texts by institutional actors and individual experts. The analysis indicates that public policies are not coherent processes, and that actors, primarily decision makers, are characterized by bounded rationality. An unusually high level of responsiveness of certain institutions (Serbian Academy of Sciences and Arts, Community of Philological and Philosophical Faculties) in resolving the second foreign language status shows their willingness to proactively address these issues.
\end{abstract}

Key words: Serbian language policy, public policy, foreign languages, 2000-2016. 


\section{ПРИЛОГ 1}

Друштво за стране језике и књижевности Србије Радна група за упоредно проучавање система образовања Март 2016. године

\section{СТРАНИ ЈЕЗИЦИ У ОБАВЕЗНОМ ОБРАЗОВАНУ У СРБИЈИ, ФРАНЦУСКОЈ, ИТАЛИЈИ, НЕМАЧКОЈ И РУСИЈИ: РЕЗИМЕ УПОРЕДНЕ АНАЛИЗЕ}

\section{Трајање обавезног школовања}

Обавезно образовање најкраће траје у Србији (8 година); у Француској и Италији траје 10 година, у Русији 11; најдуже траје у Немачкој, 12 година.

\section{Трајање школског часа}

Школски час у Србији траје 45 минута као и у Немачкој и Русији; у Француској траје 55 минута, а у Италији 55 или 60 минута.

Оптерећеност ученика у разредима који оговарају нашим вишим разредима основне школе

Најмање су оптерећени ученици у Србији: 25 школских часова за обавезне наставне предмете + 3 школска часа за изборне наставне предмете, тј. 28 х 45 мн недељно;

$\begin{array}{lll}\text { У Француској: VII разред: } 25+2, & \text { тј. } 27 \text { x } 55 \text { мн недељно; } \\ & \text { VIII разред: } 26+3,5, & \text { тј. } 29,5 \text { x } 55 \text { мн недељно; } \\ \text { У Италији: } & & 30 / 36 / 40 \text { x 55/60 мн недељно; } \\ \text { У Немачкој: } & & 30 \text { x } 45 \text { мн недељно; } \\ \text { У Русији: } & \text { VII разред: } & 32 \text { x } 45 \text { мн недељно; } \\ & \text { VIII разред: } & 33 \text { x } 45 \text { мн недељно. }\end{array}$

\section{Први страни језик}

- У Србији се учи од првог разреда као и у Француској и Италији; у Немачкој се учи од првог или трећег разреда; у Русији од другог;

- Фонд часова је најмањи у Србији, по два часа недељно;

- Очекивани ниво на крају обавезног образовања у Србији је А2, као и у Италији; у осталим земљама је виши, Б1; 
СТРАНИ ЈЕЗИЦИ У ЈЕЗИЧКОЈ ОБРАЗОВНОЈ ПОЛИТИЦИ СРБИЈЕ:

ДИНАМИКА ПРОМЕНА У ПЕРИОДУ ОД 2000. ДО 2016. ГОДИНЕ

- У Србији се најчешће учи енглески језик као и у анализираним земљама.

\section{Други страни језик}

- У Србији се учи као обавезно изборни предмет од петог разреда; од петог разреда учи се и у Италији и Русији; у Француској и Немачкој учи се од VII разреда (у Француској изузетак чине двојезичне школе у којима се учи од VI разреда);

- Фонд часова најмањи је у Србији и Русији, по два часа недељно;

- Очекивани ниво у Србији је A1+/A2, у Италији А1, док у осталим земљама није спецификован, осим у Француској, где се за крај средњег образовања очекује Б2 из првог или другог страног језика, по избору ученика (полаже се обавезно на великој матури и укључује усмено изражавање).

Љиљана Ђурић 


\section{ПРИЛОГ 2}

Друштво за стране језике и књижевности Србије

Радна група за упоредно проучавање система образовања

Март 2016. године

\section{ОПШТЕ ИНФОРМАЦИЈЕ О ОБАВЕЗНОМ ШКОЛОВАЫУ' 2016.}

\begin{tabular}{|c|c|c|c|c|}
\hline & ФРАНЦУСКА & ИТАЛИЈА & НЕМАЧКА ${ }^{2}$ & РУСИЈА \\
\hline $\begin{array}{l}\text { Трајање } \\
\text { обавезног } \\
\text { школовања }\end{array}$ & $\begin{array}{l}\text { Од шесте до } \\
\text { навршене } \\
\text { шеснаесте } \\
\text { године ученика } \\
\text { (10 година). }\end{array}$ & $\begin{array}{l}\text { Од шесте до } \\
\text { навршене } \\
\text { шеснаесте } \\
\text { године ученика } \\
\text { (10 година). }\end{array}$ & $\begin{array}{l}\text { Од напуњене } \\
\text { шесте до навршене } \\
\text { осамнаесте } \\
\text { ученика ( } 12 \\
\text { година). }\end{array}$ & $\begin{array}{l}\text { Од седме до } \\
\text { навршене } \\
\text { осамнаесте } \\
\text { године ученика } \\
\text { (11 година). }\end{array}$ \\
\hline $\begin{array}{l}\text { Однос нижих } \\
\text { и виших } \\
\text { циклуса } \\
\text { обавезног } \\
\text { образовања }\end{array}$ & $\begin{array}{l}\text { - Основна } \\
\text { школа: } 5 \\
\text { година; } \\
\text { - колеж: } 4 \\
\text { године. }\end{array}$ & $\begin{array}{l}\text {-1. први циклус } \\
\text { основне школе: } \\
5 \text { година; } \\
\text { - други циклус } \\
\text { основне школе: } \\
3 \text { године. }\end{array}$ & $\begin{array}{l}\text { - Основна школа: } 4 \\
\text { године; } \\
\text { - даље се ученици } \\
\text { распоређују по } \\
\text { гимназијама (које } \\
\text { једине воде до } \\
\text { матуре), реалкама и } \\
\text { стручнм школама; } \\
\text { неодлучни похађају } \\
\text { „општу школу“3 } \\
\text { која траје од 5. до } \\
10 . \text { разреда. }\end{array}$ & $\begin{array}{l}\text { - нижи разреди } \\
\text { (начальная } \\
\text { школа): } 4 \text { године } \\
(1-4 . \text { разред); } \\
\text { - основна } \\
\text { школа (основная } \\
\text { школа): } 5 \text { година } \\
\text { (5-9. разред); } \\
\text { - старији } \\
\text { разреди (старшие } \\
\text { классы): } 2 \text { године } \\
(10 \text { и } 11 \text { разред) })^{4} .\end{array}$ \\
\hline
\end{tabular}

1 Анализе су засноване на подацима са званичних сајтова министарстава просвете обрађених држава и рађене су фебруара 2016. године (у табелама земље су дате оним редом којим су координатору пристизале анализе): Италија - др Катарина Завишин и др Љиљана Бањанин, Немачка - др Оливера Дурбаба и др Јан Красни, Русија - др Јелена Гинић, Француска - др Љиљана Ђурић.

2 Будући да је школство у Немачкој децентрализовано, као пример изабрана је Рајнска и Фалачка област по чијим програмима ради Немачка школа у Београду. У тој покрајини страни језик нема фаворизован статус, као што је то случај са неким другим областима.

3 Чији пример даље користимо у овом приказу.

4 После 11. разреда основне школе полаже се матурски испит; пример општеобразовне школе која траје 11 године користимо у овом приказу упоредног образовања; после 9. или 11. разреда може се прећи у средње стручне школе (средние специальные учебные заведения) медицинске, правне, техничке струке и др, где образовање траје 2-4 године (уколико се пређе после 9. разреда - 4 године, после 11 - 2 године). 
СТРАНИ ЈЕЗИЦИ У ЈЕЗИЧКОЈ ОБРАЗОВНОЈ ПОЛИТИЦИ СРБИЈЕ:

ДИНАМИКА ПРОМЕНА У ПЕРИОДУ ОД 2000. ДО 2016. ГОДИНЕ

\begin{tabular}{|c|c|c|c|c|}
\hline $\begin{array}{l}\text { Tрајање } \\
\text { школског } \\
\text { часа }\end{array}$ & $\begin{array}{l}\text { - } 55 \text { минута; } \\
\text { - у нижим } \\
\text { разредима } \\
\text { могућа је и } \\
\text { другачија } \\
\text { расподела } \\
\text { недељног } \\
\text { фонда часова. }\end{array}$ & $\begin{array}{l}\text { - Један сат, } \\
\text { то јест } 60 \text { мн; } \\
\text { уколико школа } \\
\text { одлучи да час } \\
\text { траје } 55 \text { мн, } \\
\text { недостајућих } \\
5 \text { мн мора се } \\
\text { надокнадити. }\end{array}$ & - 45 минута. & $\begin{array}{l}\text { - не више од } 40 \\
\text { минута у првом } \\
\text { разреду; не више } \\
\text { од } 45 \text { минута } \\
2-11 . \text { разреда. }\end{array}$ \\
\hline $\begin{array}{l}\text { Оптерећеност } \\
\text { ученика по } \\
\text { разредима / } \\
\text { циклусима }\end{array}$ & $\begin{array}{l}\text { - Основна } \\
\text { школа: } 24 \text { сата } \\
\text { неделно / } 864 \\
\text { сата годишње; } \\
\text { - колеж: } \\
\text {. шести разред: } \\
\mathbf{2 5} \text { сати }+30 \text { мн } \\
\text { нед. по избору } \\
\text { школе + } 10 \text { сати } \\
\text { год. разредна } \\
\text { заједница; } \\
\text {. седми разред: } \\
\text { исто + факулт. } \\
\text { латински } 2 \\
\text { сата; } \\
\text {. осми разред: } \\
\mathbf{2 6}+30 \text { мн } \\
\text { нед. по избору } \\
\text { школе + } 10 \text { сати } \\
\text { год. разредна } \\
\text { зајед; + } 3 \\
\text { сата латински } \\
\text { или рег. језик } \\
\text { (факултативно); } \\
\text {. девети разред: } \\
\mathbf{2 8 , 5}+10 \text { сати } \\
\text { год. разредна } \\
\text { зајед. + } 3 \text { сата } \\
\text { латинског / } \\
\text { регионалног } \\
\text { или појачаног } \\
2 . \text { стр. ј. }\end{array}$ & $\begin{array}{l}\text {-1. први циклус } \\
\text { основне школе: } \\
\text { недељни фонд } \\
\text { часова може } \\
\text { варирати у } \\
\text { складу са } \\
\text { избором } \\
\text { породица и } \\
\text { то од } 24 \text { до } \\
\mathbf{2 7} \text { часова, а } \\
\text { може бити и } \\
\mathbf{3 0 ,} \text { односно и } \\
\text { максималних } \\
\mathbf{4 0} \text { часова; } \\
\text { - други циклус } \\
\text { основне школе: } \\
\text { недељни фонд } \\
\text { часова износи } \\
\mathbf{3 0} \text { часова. } \\
\text { У складу са } \\
\text { расположивим } \\
\text { местима и } \\
\text { активностима, } \\
\text { могуће је } \\
\text { обезбедити } \\
\mathbf{3 6} \text { часова са } \\
\text { обавезним } \\
\text { поподневним } \\
\text { часовима } \\
\text { (2 до } 3 \text { пута } \\
\text { седмично). На } \\
\text { захтев већине } \\
\text { (породица), } \\
\text { продужени } \\
\text { боравак може } \\
\text { обухватити } 40 \\
\text { часова. }\end{array}$ & $\begin{array}{l}\text { - Пети и шести } \\
\text { разред: } \mathbf{2 8} \text { часова; } \\
\text { - од седмог до } \\
\text { десетог разреда: } \mathbf{3 0} \\
\text { часова. }\end{array}$ & $\begin{array}{l}\text { 1. разред - не } \\
\text { више од } 21 \text { час } \\
\text { недељно } \\
2-4 .- \text { не више од } \\
\mathbf{2 3} \text { часа нед. } \\
5 .- \text { не више } \\
\text { од } 29 \text { часова } \\
\text { недељно } \\
6 .- \text { не више } \\
\text { од } 30 \text { часова } \\
\text { недељно } \\
7 .- \text { не више од } \\
\mathbf{3 2} \text { часа недељно } \\
8-9 .- \text { не више од } \\
\mathbf{3 3} \text { часа недељно } \\
10-11 .- \text { не } \\
\text { више од } \mathbf{3 4} \text { часа } \\
\text { недељно }\end{array}$ \\
\hline
\end{tabular}




\section{СТРАНИ ЈЕЗИЦИ У ОБАВЕЗНОМ ОБРАЗОВАҢУ}

\begin{tabular}{|c|c|c|c|c|}
\hline & ФРАНЦУСКА & ИТАЛИЈА & НЕМАЧКА & РУСИЈА \\
\hline $\begin{array}{l}\text { Први } \\
\text { страни } \\
\text { језик }\end{array}$ & $\begin{array}{l}\text { - Учи се од } \\
\text { првог разреда } \\
\text { (сензибилизација } \\
\text { може да почне у } \\
\text { вртићу); } \\
\text { - фонд часова од } \\
\text { првог до петог } \\
\text { разреда: } 90 \text { минута } \\
\text { недељно / } 54 \text { сата } \\
\text { годишње; од шестог } \\
\text { до деветог (тј. у } \\
\text { колежу): по } 3 \text { сата } \\
\text { недељно; } \\
\text { - очекивани ниво на } \\
\text { крају петог разреда: } \\
\text { А1; на крају колежа: } \\
\text { Б15; } \\
\text { - најчешће се учи } \\
\text { енглески језик, затим } \\
\text { немачки и шпански, } \\
\text { мада су у понуди } \\
\text { и други језици } \\
\text { (руски, арапски, } \\
\text { италијански...). }\end{array}$ & $\begin{array}{l}\text { - Учи се од првог } \\
\text { разреда; } \\
\text { - фонд часова } \\
\text { од првог до } \\
\text { осмог разреда } \\
\text { је минимум } 3 \\
\text { сата недељно, } \\
\text { али могуће је да } \\
\text { се учи и } 5 \text { сати } \\
\text { недељно уколико } \\
\text { родитељи } \\
\text { одаберу додатне } \\
\text { часове после } \\
\text { подне у чијим } \\
\text { трошковима } \\
\text { учествују; } \\
\text {-нивои: енглески: } \\
1 . \text { по завршетку } \\
\text { првог циклуса: } \\
\text { А1; } \\
\text { 2. по завршетку } \\
\text { другог циклуса } \\
\text { : А2; } \\
\text { - учи се обавезно } \\
\text { енглески језик. }\end{array}$ & $\begin{array}{l}\text { - Учи се од } \\
\text { првог или трећег } \\
\text { разреда; } \\
\text { - фонд часова: } \\
\text { до петог } \\
\text { разреда износи } \\
\text { по правилу } 2 \\
\text { школска часа } \\
\text { недељно (са } \\
\text { факултативним } \\
\text { понудама од још } \\
\text { једног часа), од } \\
\text { петог до десетог } \\
\text { у просеку четири } \\
\text { до четири и по } \\
\text { часа; } \\
\text { - очекивани } \\
\text { ниво на крају } \\
\text { основне школе } \\
\text { (4. разреда): } \\
\text { А1; на крају } \\
\text { тзв. додатног } \\
\text { школовања (10. } \\
\text { разреда): Б1 } \\
\text { - учи се углавном } \\
\text { енглески или } \\
\text { француски језик } \\
\text { (тј. језик земље } \\
\text { суседа). }\end{array}$ & $\begin{array}{l}\text { - Први страни } \\
\text { језик учи се } \\
\text { обавезно од } 2 . \\
\text { разреда; } \\
\text { - фонд часова: } \\
\text {.1-4. разреда: } 2 \\
\text { часа недељно; } \\
\text {. 5-11: } 3 \text { часа } \\
\text { недељн; } \\
\text { - очекивани ниво: } \\
\text { Б16; } \\
\text { - најчешће се учи } \\
\text { енглески језик, } \\
\text { али и немачки, } \\
\text { француски и } \\
\text { шпански. }\end{array}$ \\
\hline
\end{tabular}

5 На великој матури: Б2, из првог или другог страног језика, по избору ученика.

6 Ово у општеобразовним школама које нису с појачаним учењем страних језика; у оваквим школама филолошког усмерења - већи је број часова и очекивани ниво је Б2. 
СТРАНИ ЈЕЗИЦИ У ЈЕЗИЧКОЈ ОБРАЗОВНОЈ ПОЛИТИЦИ СРБИЈЕ: ДИНАМИКА ПРОМЕНА У ПЕРИОДУ ОД 2000. ДО 2016. ГОДИНЕ

\begin{tabular}{|c|c|c|c|c|}
\hline $\begin{array}{l}\text { Други } \\
\text { страни } \\
\text { језик }\end{array}$ & $\begin{array}{l}\text { - Учи се обавезно } \\
\text { од седмог } \\
\text { разреда; одељења } \\
\text { са двојезичном } \\
\text { наставом почињу да } \\
\text { га уче од шестог; } \\
\text { - фонд часова: } 3 \text { сата } \\
\text { недељно; одељења } \\
\text { sections européennes } \\
\text { и sections de langues } \\
\text { orientales у осмом } \\
\text { и деветом р. имају } \\
\text { појачану наставу } \\
\text { другог страног језика } \\
\text { (додатна два сата); } \\
\text { - најчешће се } \\
\text { уче немачки или } \\
\text { шпански језик. }\end{array}$ & $\begin{array}{l}\text { - Учи се обавезно } \\
\text { од петог разреда } \\
\text { (у другом } \\
\text { циклусу основне } \\
\text { школе); } \\
\text { - фонд часова је } \\
\text { два сата недељно; } \\
\text { - по завршетку } \\
\text { другог циклуса: } \\
\text { А1; } \\
\text { - други страни } \\
\text { језик некада } \\
\text { зависи од регије - } \\
\text { нпр. у Пијемонту } \\
\text { је то француски } \\
\text { језик. }\end{array}$ & $\begin{array}{l}\text { - Учи се обавезно } \\
\text { од седмог } \\
\text { разреда; } \\
\text { - фонд часова је } \\
\text { најчешће по } 4 \\
\text { часа од седмог } \\
\text { до деветог и } 3 \\
\text { часа у десетом } \\
\text { разреду; } \\
\text { - по правилу се } \\
\text { учи француски } \\
\text { језик. }\end{array}$ & $\begin{array}{l}\text { - Учи се обавезно } \\
\text { почев од } 5 . \\
\text { разреда'; } \\
\text { - фонд часова је } 2 \\
\text { недељно; } \\
\text { - најчешће се } \\
\text { уче немачки или } \\
\text { француски, али } \\
\text { може бити и } \\
\text { енглески итд.. }\end{array}$ \\
\hline
\end{tabular}

7 До ове године почињало се у седмом или осмом разреду. Од јесени 2016. реформом се генерализује почетак учења другог страног језика од седмог разреда, тако да се фонд повећава за 54 сата годишње.

8 Ово је информација са сајта министарства образовања покрајине Порајње-фалачке (Rheinland-Pfalz) и потиче из 2004. године.

9 Обавезно учење уведено је школске 2015/16. године. 


\section{ПРИЛОГ 3}

Друштво за стране језике и књижевности Србије, Радна група за упоредно проучавање система образовања Март 2016. године

\section{МАТЕРЫИ ЈЕЗИК/ЈЕЗИЦИ У ОБАВЕЗНОМ ОБРАЗОВАЫУ 2016.}

\begin{tabular}{|c|c|c|c|c|}
\hline & ФРАНЦУСКА & ИТАЛИЈА & НЕМАЧКА & РУСИЈА \\
\hline $\begin{array}{l}\text { Матерњи } \\
\text { језик/језици } \\
\text { или језици } \\
\text { образовања }\end{array}$ & \begin{tabular}{|l} 
Француски \\
језик: \\
- Основна \\
школа: \\
. први и други \\
разред: 10 сати \\
недељно; \\
. трећи, четврти \\
и пети разред: 8 \\
сати недељно. \\
- Колеж: \\
. шести разред: \\
четири и по до 5 \\
сати недељно; \\
. седми и осми \\
разред: 4 сата \\
недељно; \\
.последњи \\
разред колежа \\
који одговара \\
нашем првом \\
разреду средње \\
школе: \\
четири и по сата \\
недељно.
\end{tabular} & $\begin{array}{l}\text { Италијански језик: } \\
\text { - Основна школа: } \\
\text {-la scuola primaria } \\
\text { (траје } 5 \text { година): } \\
\text { минимум - } 6 \text { сати } \\
\text { недељно, } \\
\text { максимум - од } 7 \text { до } \\
8 \text { сати недељно. } \\
\text {-la scuola secondaria } \\
\text { di primo grado } \\
\text { (траје } 3 \text { године): } \\
\text { од } 5 \text { до } 6 \text { сати } \\
\text { недељно } \\
\text { (-Средња школа: } \\
\text { seсопdo сісlo } \\
\text { (sесопdaria di } \\
\text { seсопdo grado): } \\
\text { гимназије и стручне } \\
\text { школе трају укупно } \\
5 \text { година, неке } \\
\text { стручне школе } \\
\text { трају } 2 \text { или } 3 \\
\text { године. Обавезно } \\
\text { школовање за све } \\
\text { средње школе } \\
\text { подразумева } 2 \\
\text { године: } \\
4 \text { сата недељно.) }\end{array}$ & $\begin{array}{l}\text { Немачки језик: }{ }^{1} \\
\text { основна школа (4 } \\
\text { године): } \\
\text {-прве две године } \\
\text { настава немачког језика } \\
\text { изводи се заједно са } \\
\text { више других часова у } \\
\text { укупном трајању од } 16 \\
\text { часова недељно. } \\
\text {-у трећем и четвртом } \\
\text { разреду немачки се учи } \\
6 \text { часова недељно. } \\
\text { Од петог до десетог } \\
\text { тј. дванаестог разреда } \\
\text { - у зависности од } \\
\text { покрајине - немачки се } \\
\text { учи од } 3 \text { до } 5 \text { изнимно } \\
\text { до } 6 \text { часова недељно у } \\
\text { зависности од профила, } \\
\text { изабраних предмета и } \\
\text { врсте школе. } \\
\text {-Матерњи језик може се } \\
\text { учити паралелно исто } \\
\text { као и немачки ако број } \\
\text { ђака то дозвољава. } \\
\text {-Немачки као други } \\
\text { језик (за досељеник) се } \\
\text { организује по потреби. }\end{array}$ & $\begin{array}{l}\text { Руски језик: } \\
\text { 1. и 2. разред: } \\
5 \text { часова } \\
\text { језика и } 4 \text { часа } \\
\text { књижевности }{ }^{2} ; \\
\text { 3. разред: } 5 \\
\text { часова језика, } 3 \\
\text { књижевности; } \\
4 . \text { разред: } 4 \\
\text { часа језика, } 3 \\
\text { књижевности; } \\
\text { 5. разред: } 4 \\
\text { часа језика, } 2 \\
\text { књижевности; } \\
6 \text { и } 7 . \text { разред: } 5 \\
\text { часова језика, } 2 \\
\text { књижевности; } \\
8 . \text { разред: } 4 \\
\text { часа језика, } 2 \\
\text { књижевности; } \\
9 . \text { разред: } 3 \\
\text { часа језика, два } \\
\text { књижевности; } \\
10 . \text { и } 11 . \text { разред: } \\
2 \text { часа језика, } 3 \\
\text { књижевности. }\end{array}$ \\
\hline
\end{tabular}

1 Немачки језик подразумева традиционално језик и књижевност, али, посебно у старијим разредима, и елементе медијске писмености која до краја школовања постаје све важнији елемент овог предмета. На крају ова област покрива скоро трећину програма наставе немачког језика.

2 Часови матерњег језика и књижевности представљају у Русији два различита предмета током целог обавезног образовања; предмет који ми у документу именујемо „књижевност” се у Русији од 1. до 4. разреда зове «литературное чтение», док се од 5. до 11. зове «литература». 


\section{ПРИЛОГ 4}

Друштво за стране језике и књижевности Србије, Радна група за упоредно проучавање система образовања Март 2016. године

\section{МАТЕРЊИ ЈЕЗИК У ОБАВЕЗНОМ ОБРАЗОВАЊУ У СРБИЈИ, ФРАНЦУСКОЈ, ИТАЛИЈИ, НЕМАЧКОЈ И РУСИЈИ: РЕЗИМЕ УПОРЕДНЕ АНАЛИЗЕ ${ }^{1}$}

\section{Трајање обавезног школовања}

Обавезно образовање најкраће траје у Србији (8 година); у Француској и Италији траје 10 година, у Русији 11; најдуже траје у Немачкој, 12 година.

\section{Трајање школског часа}

Школски час у Србији траје 45 минута као и у Немачкој и Русији; у Француској траје 55 минута, а у Италији 55 или 60 минута.

\section{Оптерећеност ученика у разредима који оговарају нашим вишим разредима основне школе}

Најмање су оптерећени ученици у Србији: 25 школских часова за обавезне наставне предмете +3 школска часа за изборне наставне предмете, тј. 28 х 45 мн недељно;

$\begin{array}{lll}\text { У Француској: VII разред: } 25+2, & \text { тј. } 27 \text { x } 55 \text { мн недељно; } \\ & \text { VIII разред: } 26+3,5, & \text { тј. } 29,5 \text { x } 55 \text { мн недељно; } \\ \text { У Италији: } & & 30 / 36 / 40 \text { x } 55 / 60 \text { мн недељно; } \\ \text { У Немачкој: } & & 30 \text { x } 45 \text { мн недељно; } \\ \text { У Русији: } & \text { VII разред: } & 32 \text { x } 45 \text { мн недељно; } \\ & \text { VIII разред: } & 33 \text { x } 45 \text { мн недељно. }\end{array}$

1 Анализе су засноване на подацима са званичних сајтова министарстава просвете обрађених држава и рађене су марта 2016. године (у табелама земље су дате оним редом којим су координатору пристизале анализе): Италија - др Катарина Завишин, Немачка - др Јан Красни, Русија - др Јелена Гинић, Француска - др Љиљана Ђурић. 


\section{Матерњи језик}

У нижим разредима основне школе, фонд часова српског / матерњег језика најмањи је у Србији, по пет часова недељно у сва четири разреда;

У вишим разредима основне школе фонд часова српског / матерњег језика најмањи је у Србији, по пет часова недељно у V, и по четири у VI, VII и VIII разреду, слично као у Немачкој, док је у осталим земљама већи;

У Србији, као у Француској, Италији и Немачкој, у наставном плану обавезног образовања не појављују се посебни часови за језик и за књижевност, што је случај у Русији.

Љиљана Ђурић 